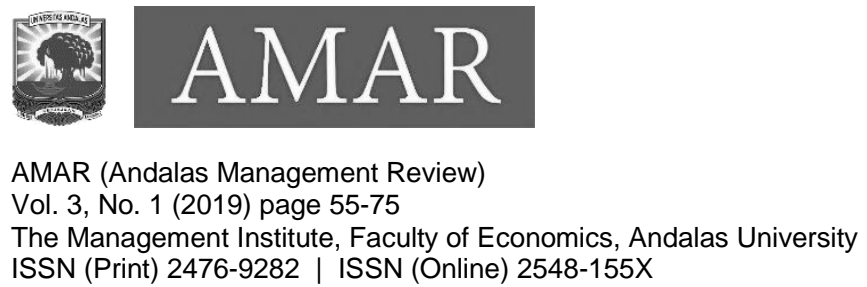

\title{
Developing Psychological Contracts of Justice in Improving Employee's Satisfaction at Perum Damri
}

\author{
Akmal, Elfitra Azliyanti \\ Management Department, Faculty of Economics, Bung Hatta University \\ drakmal210@gmail.com, elfitra.azliyanti@gmail.com
}

\begin{abstract}
This study aims to examine the predictors and consequences of a fair psychology contract. There are relationships between the degree of reciprocal trust and fair psychological contracts, reward mechanisms for fair psychology contracts, assessment of actual performance to a psychological contract of justice, intrinsic motivation to equitable psychology contracts, equitable psychological contracts on job satisfaction and Intrinsic motivation and Job satisfaction. The population of this study is 205 staff at Perum Damri Regional Division II and data was collected using a purposive sampling technique. The criteria of the respondents chosen were staff or employees who had worked in Damri's general company for at least 1 year. Data analysis techniques in research using software smart PLS 2.0 M3. This study contains 6 hypotheses and from the research, the results of reciprocal degrees of trust influence the fair psychology contract, but the progressive reward mechanism, the assessment of actual performance and intrinsic motivation have no effect. While fair psychology contracts and intrinsic motivation affect employee job satisfaction.
\end{abstract}

Keyword: intrinsic motivation, human resource management practices, equitable psychological contracts.

\section{INTRODUCTION}

Competition in the global market, the company strives to provide special services to customers and offers innovative and value-added products. Organizations tend to carry out restructuring, mergers and acquisitions that make organizations make changes in managing their workforce (Cappeli, 1999). Today a number of people carry out the process of learning, writing and business people often argue whether we should ignore human resources? The debate raises serious and widespread doubts about the benefits of human resources on organizational performance. The reason is that human resources are often ineffective, incompetent and expensive, in short weakening values (Ulrich, 1997). An HRM practice contributes to the economic success of an organization through increasing job satisfaction. 
Ostroff and Bowen (2004) support that HR practices have a significant effect on employees' perceptions and attitudes but there are still few systematic attempts that are clearly mediation processes and how to influence organizational effectiveness.

Organization provides employees with what is promised and valued by the company will shape positive attitudes and behaviors. The perceived injustice in the work relations promised by the company results in attitude and behavior alteration (Kickul, 2001). The Alniacik et al (2013) study also shows the mechanism of psychological contract satisfaction that affects organizational commitment and job satisfaction when psychological contracts of knowledge workers are fulfilled (the obligations required by the organization are effectively fulfilled), they will feel physical and psychological incentives.

One challenge that must be faced by organizations today is managing changes in the relationship between employees and organizations. Human resource practices have an impact on organizational performance by creating efficient structures and operations. The human resource system will reduce employee turnover (Guthrie, 2001). Human resource management practices can influence relationships between employees and influence the perception of contract psychology (Sonnenberg \& Koene, 2011) and have an impact on employee behavior and organizational outcomes. Based on the background, the research problem can be formulated as follows "How to manage human resource management practices by developing psychological justice contracts to improve job satisfaction?"

\subsection{Relationship Between the Degree of Reciprocal Trust and Fair Psychology Contracts Psychology}

Contract violations can result in reduced elements of trust in the relationship between organizations and employees, (Deery, Iverson, \& Walsh, 2006) and results in anger and low trust. If both parties, namely the organization and employees maximize their relationship, then there is a mechanism by which both can work together effectively because the central role of trust in relationships has a direct influence on how the two work together (Coyle-Syapiro, 2002).

Guest and Conway (2001) found that one key influence of employee trust is whether or not the organization has fulfilled its psychological contract. Clinton and Guest (2004) found that the relationship between trust and contract psychology was high and reported at $r=.43$. The study found that $17 \%$ of 136 employees who were respondents believed that their organization had failed to fulfill its obligations and trust mediated the relationship between violations of 
psychological and performance contracts, OCB, commitment, job satisfaction, and the desire to leave. Furthermore, Lijo \& Amurtha (2013) also found that work involvement, quality of life and trust were more common among permanent and long-term employees with clear psychological contracts than contract employees. Based on the results of research and review, the following hypotheses are formulated:

\section{H1: Degree of reciprocal trust has a positive effect on fairness psychology contracts}

\subsection{Relationship between Progressive Reward Mechanisms for Fair Psychology Contracts}

A fair wage in agreement between employees and organizations is assumed to be money that can influence behavior ( Parker and Wright, 2001). They tend to stick with organizations when they feel that their capabilities, effort, and performance contributions are recognized and valued (Davies, 2001) and awards have been recognized as an important element of psychological contracts which means relationships between employees and organizations. The accuracy of the award management system will motivate the application of expertise, abilities and work as well as the improvement of work processes.

The researcher supports that compensation and benefits provided by employee organizations have a major impact on contract psychology (Rousseau 1990). There are two basic dimensions, namely duration (short or long term) and type of compensation (specific or not specific). Rousseau (1990) relates the type of compensation to the physical contract called the type of relationship, namely (1) short-term relationships with specific performance measurements, (2) long-term relationships with non-specific performance measurements, (3) long-term relationships with specific performance, and (4) long-term relationships with nonspecific performance. Organizations can design compensation systems based on the type of relationship they want to maintain. For example organizations want the establishment of longterm relationships with specific performance measurements, so the organization prepares a compensation structure that invests employees with training based on special skills, where the organization invests its employees in training based on expenditure expertise, flexible system benefits, short-term and long-term incentives. Alternatively, when organizations with long term and performance measurements are not specific, their compensation is based on seniority and institutional awards such as bonuses based on years of service. Organizations with a short-term relationship strategy will make short-term awards for performance such as sales commissions 
or non-cash awards such as free tours, free meals for families in restaurants in achieving sales targets.

Psychology contracts also affect their expectations of the type of compensation. For example employees who work short-term with specific performance indicators, then they will be more compensated for short-term performance such as sales commissions. Employee involvement in decision making and benefits planning is an important tool to prevent the perception of psychological contract irregularities. Based on the illustration of the review, how compensation and benefits affect psychological contracts can be used as a signal mechanism to establish this type of relationship.

\section{H2: Progressive reward mechanisms have a positive effect on contract psychology justice}

\subsection{Relationship between Actual Performance Assessment of Equitable Psychology Contracts}

Performance appraisal is the process of organizational involvement forming performance standards and providing employees with feedback about their level of performance. Contracting that is characterized by performance management includes understanding the role of work, fairness, time, and accurate evaluation of performance, equitable distribution of payments and the development of opportunities and performance provisioning feedback. Among HR practices, the performance management process plays a key role in determining employee-organizational expectations (Lester and Kickul, 2001). In fact, the study views that the biggest issue and the greatest contribution of human resources can make changes to the scenario of relations to evaluation and assessment.

Environmental competition makes performance management the center stage with the specifications of new performance requirements as a result of strategic change, and the rewards they receive when fulfilled. Performance appraisal can affect relationships in various ways. Lester and Kickul (2001) support that organizations can improve their ability to fulfill psychological contracts through high-value psychological contract targets on their job reviews . After the information is collected about the best results of the initial process, employees can be specific about what the candidate expects in their employment relationship. When organizations provide feedback to employees about their achievements, it is a sign of employees whether or not they are contributing to their work relationship. Development of assessments in 
line with the long term and specific / non-specific performance measures, career management and payment based on expertise will produce a strong working relationship.

If $\mathrm{HR}$ practices are not in the same direction as sending employee messages and may also result in an increase in the issue of perceptions of injustice. Therefore, performance appraisal has been identified as an opportunity for employees to indicate their responsibilities to the organization and as a signal for the organization to influence employees about their psychological contracts. Performance evaluation is important as an opportunity for employees to receive appropriate feedback on their performance and help them correct the mistakes of two parties, who have fulfilled the contractual psychology section (Rousseau, 2001).

\section{H3: Assessment of actual performance positively influences the psychological contract of justice}

\subsection{Relationship of Intrinsic Motivation and Equitable Psychology Contracts}

The role of psychological empowerment in facilitating creativity, there is evidence of the relationship between psychological empowerment and intrinsic motivation. Zhang \& Bartol (2010) state that empowering leaders are positively related to psychological empowerment. The role of empowerment moderates the relationship between empowering leadership and psychological empowerment.

Physical contract is a set of subjective beliefs about the exchange of relationships between employees and organizations. Modern organizations need change and adaptation to survive. The implication is that long life relationships in psychological contracts are not valid in the long run and the fundamental relationship between employees and organizations has changed. Employees may perceive these changes as a violation of physical contracts that lead to decreased job satisfaction, motivation, productivity, and increased effort to leave the organization. Furthermore, differences in the types of psychological contracts will be treated differently also for employee reactions. Research illustrates that the relationship between exchange of beliefs, job satisfaction and organizational commitment supports the importance of psychological statements.

Employees have different needs based on demographics, aspirations, desires and personality. For motivation at a high level like an interesting job and recognition. Expectations of employees to be treated fairly and fair rewards will affect their business (Kim and Maourgone, 2003). Perception of injustice produces actions such as leaving the organization 
(Huczynski and Buchanan, 2007) and motivation as a cognitive in the decision-making process through goal-directed behavior means individual motivation is the result of desires that affect behavior and strive to achieve these results. Lange et.al., (2011) found that violations of physical contracts were negatively related to work motivation.

Some studies found that empowerment can enlarge employees' efforts and increase employee effort when given autonomy, Wang (2010) found that psychological empowerment was positively related to intellectual motivation. Other empirical studies state that factors of participation in decision making, organizational support, and organizational justice have a major impact on work motivation and work performance. Positive impact on the organization will make employees develop emotional positives.

Liu \& Fang (2006) found that power sharing behavior significantly and substantially explained variation in individual performance throughintrinsic and extrinsicmotivation. This finding is instructive as support that the relationship between empowerment and indirect performance. Dewettinck et., Al (2003) found that empowerment has a significant relationship and is considered with the affective results of employees. Chen et. Al. (2007) found empirical evidence that there is a direct relationship between empowerment and performance. Therefore, based on theoretical arguments and previous research on the relationship between psychological empowerment elements andintrinsicmotivation, the following hypotheses are formulated:

\section{H4: Intrinsic motivation has a positive effect on psychological contracts of fairness Psychology Contract Relationships and Job Satisfaction}

\subsection{Relationship Between Equitable psychological contracts on job satisfaction}

Psychological contracts are individual beliefs about obligations reciprocity in multiple relationships in multiple relationships such as work (Sebastian, 2015). Psychological contracts refer to the expectations of employees and employers with each other and what they owe to each other (Agarwal, 2014). Johnson and O'Leary-Kelly (2003) found that there was a negative relationship between violations of psychological contracts and job satisfaction and commitment and violations of contract psychology predicting employee behavioral responses such as suppressing in-role performance and increasing absenteeism. Lester et., $\mathrm{Al}$ (2002) found that the greater the level of psychological contract violations by subordinates, the less commitment to the organization. 
Job satisfaction is an internal statement expressed by cognitive and affective evaluations in the work environment with levels of likes or dislikes (Brief \& Weis, 2002). The results of Jonhson and O'Leary-Kelly's (2003) study state that there is a relationship of -0.59 between violations of psychological contracts and job satisfaction.

Tekleab and Taylor (2003) state that there is a correlation of -0.34 between psychological contracts and job satisfaction. When job satisfaction increases, psychology contracts also increase (Lamberts, Edwards, and Cable (2003). The results of this study are also supported by Clinton and Guest (2004) who reported that a significant correlation of 0.35 between full contract psychology and job satisfaction. Paul et, al (2000) based on expectation theory that supports the relationship between psychological contracts and satisfaction Spreitzer (2008) found that attitudinal and behavioral outcomes have a relationship to psychology empowerment because psychology empowerment meets the intrinsic needs of autonomy and growth for example finding job satisfaction, commitment, and retention as a result of empowerment. Mibert et. al. (2011) found that psychology empowerment was positively related to employee achievement such as job satisfaction, organizational commitment, assignment and contextual achievement, but negatively related.towards turnaround and tension intentions.

Zhou et al (2014) found a positive relationship between psychological contracts and job satisfaction When workers consider their psychological contracts to be fulfilled, they will form a strong sense of identification and loyalty to the organization and they feel proud and have the satisfaction of being members of the organization. Thus, they feel they have an obligation and responsibility to work in the organization. In addition, a survey of $342 \mathrm{HR}$ professionals has noticed that relationships with direct superiors, opportunities to use skills and abilities and communication between employees and senior management, autonomy and independence, organizational financial stability, work psychology contracts are themselves contributors to large job satisfaction (Employee Job Satisfaction, 2014). Established relationships between the factors mentioned above and the effectiveness of HR professional organizations and job satisfaction will be the result of a strong psychological contract between the organization and HR employees in the long run.

Lijo and Lyngdoh (2016) state that Psychology Contracts have a positive relationship with job satisfaction. Employees need support and constant encouragement from management on a large scale. So, psychological contract agreements are very important for fresher HR 
employees to commit and get job satisfaction from those commitments. Based on the literature and arguments above, the following hypotheses are formulated:

\section{H5: Equitable psychological contracts have a positive effect on job satisfaction}

\subsection{Relationship between Intrinsic Motivation and Job Satisfaction.}

Environments such as materials, tools, equipment, budget and financial support affect employee training motivation (Tracey et. Al. 2001). Tabassi et., Al (2011) found that there was a relationship between the practice of training motivation on improving task performance and efficiency. Among the types of motivation, intrinsic motivation has a large impact on employee attitudes (Deci \& Ryan, 2004). Low et al., (2001) also found that intrinsic motivation has a positive relationship to sales staff job satisfaction. Gagne \& Deci (2005) support that employees who have high intrinsic motivation will be more involved in their work.

Employee development and training is one of the researches on work psychology (Chen \& Klimoski, 2007). Previous research found that the relationship between perceived training opportunities and employee outcomes was mediated through a number of individual differences and situational ariables (Meyer \& Smith, 2000). Deci \& Moller (2005) argues that motivation must be studied as a mediation of how perceived relevance of training impacts motivation and as a moderation as how motivation relates to the desire to learn, for the relationship between the development reaction and employee training towards work outcomes. Leat \& Al-Kot, (2009) found that there was a positive correlation between intrinsic motivation for work attitudes (job satisfaction).

Liu et., Al (2006); Manojlovich \& Laschinger (2002) have found that there is a positive relationship between empowerment, job satisfaction and organizational commitment. DeCicco et., $\mathrm{Al}$ (2006) found that nurses who have high satisfaction with their work and commitment to the organization are better when they feel empowered. Chang et., Al (2010) found that psychology empowerment did not mediate in full the relationship between organizational empowerment and job satisfaction because of the strong direct influence of organizational empowerment on job satisfaction. Motivationintrinsic not only increases effort, buthas a big influence on other aspects of behavior. Lee \& Nie (2014) found that psychology empowerment (meaning and autonomy) mediates the relationship between teacher perceptions of supervisory empowerment behavior on the results of teacher work relationships. Johnson et al. (2010) say 
that commitment is a motivational phenomenon and when workers have a commitment it will generate a contribution to the organization.

Rowden \& Conine (2005) proposed that training motivation might be used as a tool to increase job satisfaction. Tsai et., Al (2007) found that employees who were committed to learning showed a higher level of job satisfaction that was positive in their performance. Arasli et al., (2014) stated that there was a positive and significant relationship between intrinsic motivation and job satisfaction. Based on the illustrations and arguments above, the hypothesis is formulated as follows:

H6: Intrinsic motivation has a positive effect on job satisfaction.

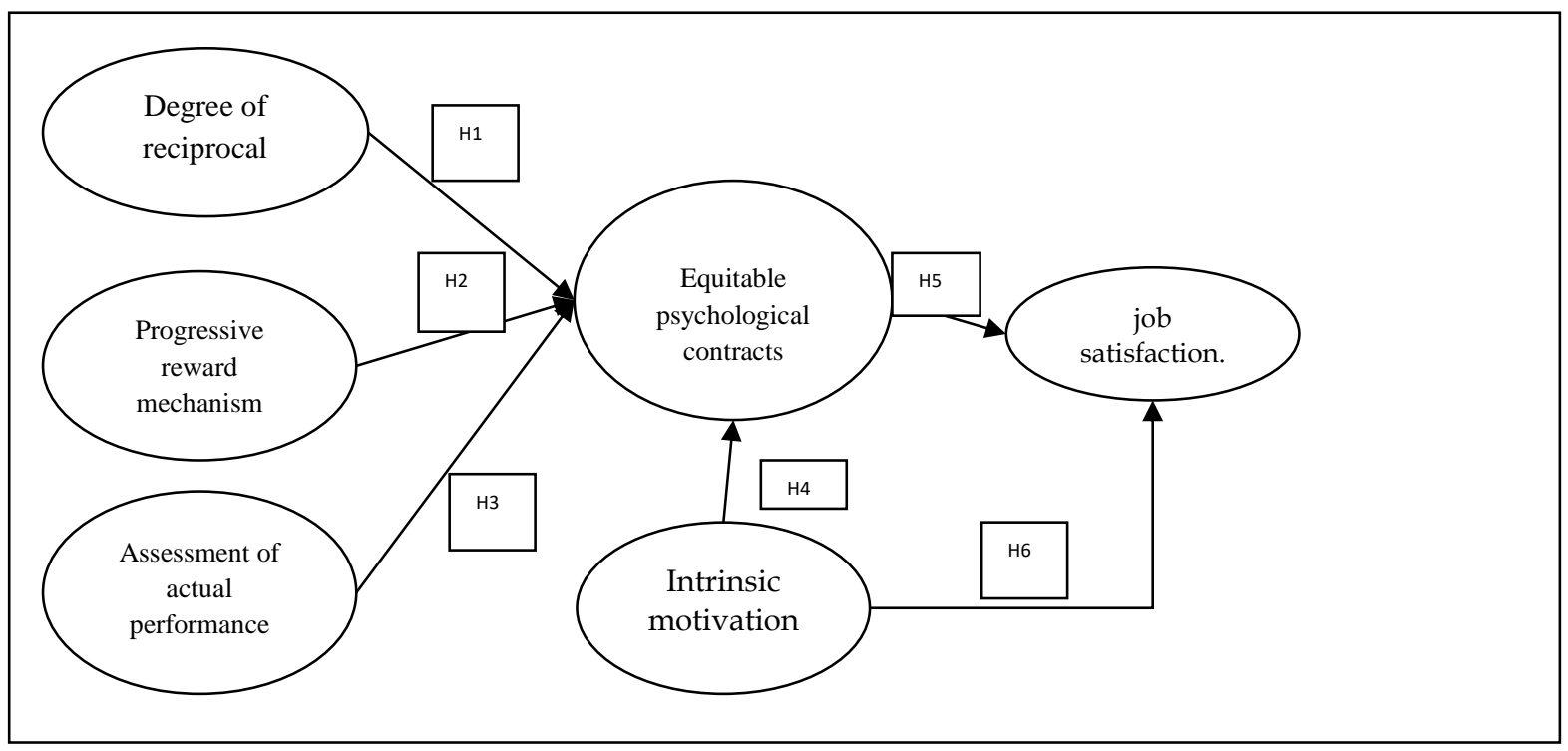

Figure 1. Research Model

\section{METHOD}

Population in this study is the state-owned company Perum and is engaged in land transportation namely Perum Damri Regional Division II. In this study the sample used was employees at Damri Regional Division II, which included Semarang, Jogjakarta, Solo, Purwokerto, Cilacap, Purworejo, Pontianak, Samarinda, Palangkaraya, and Banjarmasin. The number of samples in this study were 330 samples with a reason to use this amount meets the criteria the number of adequacy of samples recommended for the technique of maximum likelihood estimation (MLE) and the criteria of average error variance of indicator (AVE) with a 
minimum sample of up to 150 with the proviso standardized loading estimates less from 0.7 and the communal value is equal to 0.5 (Hair et al., 2010).

The sampling technique used in this study was purposive sampling, namely sampling or selection of respondents based on certain criteria to fit the research objectives. The criteria of the respondents chosen were staff or employees who had worked in Damri's general company for at least 1 year. The consideration is that employees who work at least one year are considered to be well-established to carry out social interactions with colleagues, direct supervisors and company management. In addition, these employees can assess various policies, rules and ways to interact with superiors. Employees like this have been able to provide an assessment to management regarding themselves and the work unit they work for.

Before conducting this research at Perum Damri, the researchers tried to contact the senior HR assistant manager by telephone and met in Jakarta to possibly allow research at the company. This study uses a survey method by distributing questionnaires to employees at Damri Regional Corporation II General Company which includes Semarang, Jogjakarta, Purwokerto, Cilacap, Solo, Purworejo, Pontianak, Palangkaraya, Banjarmasin, and Samarinda. The period of questionnaire collection is 75 days since the questionnaire was sent by express mail. The main data used in this study are primary data obtained through questionnaires as the only tool in data collection. In addition, researchers also use secondary data.

In this study we will examine the relationship between all constructs and subconstructs using structural equation modeling (SEM). The SEM equation model is a set of statistical techniques that allows testing of a series of relatively complex relationships simultaneously. These complex relationships are built between one or several dependent variables with one or several independent variables. In addition, SEM is suitable to be used to confirm the unidimensionality of various indicators for a construct / concept / factor, test the suitability / accuracy of a model based on the empirical data studied, and test the suitability of the model and causality between the factors constructed / observed in the model .

\section{DATA ANALYSIS}

Analysis techniques in this study through two general stages, namely measurement model and structural model. Both of these stages will be analyzed using software smartPLS 2.0M3. The reason for using software this in research is because the research model used is multidimensional 
in nature and consists of many indicators (Ghozali, 2008). Testing instruments (measurement model) is needed to guarantee the accuracy of the measurement results of the research variables so as to improve the scientific quality of the writing (Cooper \& Schindler, 2008). After testing the instrument, testing the structural model (structural model) also needs to be done to test all the hypotheses put forward, so that the problems in this study can be answered.

Validity of the instrument for the indicator in the reflective construct was evaluated based on convergent and discriminant validity of the indicator run using the SmartPLS software 2.0 M3. Convergent validity is assessed based on correlation (outer loading) between the score of the item or indicator (component score) and the construct score. Convergent validity is used to determine the validity of each relationship between the indicator and its latent construct. Convergent validity is said to be high if the value of loading or indicator score correlates with a construct score above 0.70 (Chin in Ghozali, 2008). Indicators whose loading is less than 0.70 area dropped from the analysis and re estimated.

The value of outer loading of each indicator at the start of testing the instrument still shows invalid results. In the initial instrument test, 3 invalid indicators have an value outer loading below 0.50 . The indicators are all deleted and then the data is rerun runtil the sixth estimate. From the results of the eight estimation instrument test, all indicators have an value outer loading above 0.50 . However, convergent validity in this case still needs to be tested by looking at the AVE (Average Variance Extracted) value. Table 1 below shows the AVE value of the results of the initial instrument test to the sixth re estimation

Table 1

AVE Value

\begin{tabular}{llllllll}
\hline $\begin{array}{l}\text { Dimension/ } \\
\text { Variable }\end{array}$ & Initial & $\begin{array}{l}\text { AVE } \\
\text { Rees 1 }\end{array}$ & $\begin{array}{l}\text { AVE } \\
\text { Rees 2 }\end{array}$ & $\begin{array}{l}\text { AVE } \\
\text { Rees 3 }\end{array}$ & $\begin{array}{l}\text { AVE } \\
\text { Rees 4 }\end{array}$ & $\begin{array}{l}\text { AVE } \\
\text { Rees 5 }\end{array}$ & $\begin{array}{l}\text { AVE } \\
\text { Rees 6 }\end{array}$ \\
\hline Trust & 0.727728 & 0.727728 & 0,727728 & 0,727728 & 0.727729 & 0.727641 & $\mathbf{0 . 7 2 7 4 5 1}$ \\
\hline Job Satisfaction & 0.475657 & 0.513373 & 0.513373 & 0.553353 & 0.553353 & 0.57025 & $\mathbf{0 . 6 3 3 3 5 1}$ \\
\hline $\begin{array}{l}\text { Knowledgeable } \\
\text { Psychology }\end{array}$ & 0.534406 & 0.534411 & 0.534401 & 0.534391 & 0,534383 & 0.603611 & $\mathbf{0 . 7 0 4 7 3}$ \\
Contracts & & & & & & & \\
\hline $\begin{array}{l}\text { Intrinsic } \\
\text { Motivation }\end{array}$ & 0.648537 & 0.648579 & 0.648579 & 0.648431 & 0.648431 & 0.743058 & $\mathbf{0 . 7 4 3 0 5 8}$ \\
\hline $\begin{array}{l}\text { Award } \\
\text { Mechanism }\end{array}$ & 0.496233 & 0.496222 & 0.55544 & 0.610448 & 0.710627 & 0, & $\mathbf{0 . 7 0 9 5 6 5}$ \\
\hline & & & & & & 710443 & \\
\hline
\end{tabular}




\begin{tabular}{|c|c|c|c|c|c|c|c|}
\hline $\begin{array}{l}\text { Dimension/ } \\
\text { Variable }\end{array}$ & Initial & $\begin{array}{l}\text { AVE } \\
\text { Rees } 1 \\
\end{array}$ & $\begin{array}{l}\text { AVE } \\
\text { Rees } 2 \\
\end{array}$ & $\begin{array}{l}\text { AVE } \\
\text { Rees } 3 \\
\end{array}$ & $\begin{array}{l}\text { AVE } \\
\text { Rees } 4 \\
\end{array}$ & $\begin{array}{l}\text { AVE } \\
\text { Rees } 5 \\
\end{array}$ & $\begin{array}{l}\text { AVE } \\
\text { Rees } 6\end{array}$ \\
\hline Actual & 0.474277 & 0.541977 & 0.541977 & 0.582311 & 0.582312 & 0.644765 & 0.64482 \\
\hline \multicolumn{8}{|l|}{ Performance } \\
\hline Rating & & & & & & & \\
\hline
\end{tabular}

Source: Results of Data Obtaining SmartPLS 2.0 M3 (2016)

In table 1 above the AVE value on the results of the estimation test the eighth shows that all dimensions and variables already have AVE values as required $(>0.50)$. This shows that all indicators left in the results of the sixth estimation instrument test have met the convergent validity test.

In the next step the researchers tested discriminant validity. Discriminant validity is used to show that the construct or latent variable predicts the size of their block is better than the size of the other blocks. Discriminant validity can be seen from the value cross loading. The indicator correlation value for the construct must be greater than the correlation value between the indicators and the other constructs. The value of cross loading shows the correlation of the score of each indicator to the dimensions and the variables are greater than the correlation of the score of the indicator to other dimensions and to other variables. This shows that this research has fulfilled the rule of thumb from the value cross loading required.

Another way to measure discriminant validity is to compare the roots of the AVE of a construct must be higher than the correlation between latent variables. AVE Root Value and correlation between constructs can be seen in table 2 below.

Table 2

AVE Root and Latent Variable Correlations

\begin{tabular}{|c|c|c|c|c|c|c|}
\hline & Trust & $\begin{array}{l}\text { Job } \\
\text { Satisfaction }\end{array}$ & $\begin{array}{l}\text { Contract } \\
\text { Knowledge } \\
\text { Psychology }\end{array}$ & $\begin{array}{l}\text { Intrinsic } \\
\text { Motivation }\end{array}$ & $\begin{array}{l}\text { Award } \\
\text { Mechanism }\end{array}$ & $\begin{array}{l}\text { Assessment of } \\
\text { Actual } \\
\text { Performance }\end{array}$ \\
\hline Trust & 0.852907 & & & & & \\
\hline Job & 0.751811 & 0.795834 & & & & \\
\hline \multicolumn{7}{|l|}{ Satisfaction } \\
\hline Contract of & 0.722329 & 0.657918 & 0.839482 & & & \\
\hline \multicolumn{7}{|l|}{ Knowledge } \\
\hline \multicolumn{7}{|l|}{ Psychology } \\
\hline Intrinsic & 0,626188 & 0.625885 & 0.607776 & 0.862008 & & \\
\hline Motivation & & & & & & \\
\hline
\end{tabular}


Andalas Management Review, Vol. 3 No. 1, 2019

\begin{tabular}{llllllc}
\hline & Trust & $\begin{array}{l}\text { Job } \\
\text { Satisfaction }\end{array}$ & $\begin{array}{l}\text { Contract } \\
\text { Knowledge } \\
\text { Psychology }\end{array}$ & $\begin{array}{l}\text { Intrinsic } \\
\text { Motivation }\end{array}$ & $\begin{array}{l}\text { Award } \\
\text { Mechanism }\end{array}$ & $\begin{array}{c}\text { Assessment of } \\
\text { Actual } \\
\text { Performance }\end{array}$ \\
\hline Award & 0.69045 & 0.687175 & 0.664386 & 0.50121 & $\mathbf{0 . 8 4 2 3 5 7}$ & \\
Mechanism & & & & & & \\
\hline $\begin{array}{l}\text { Rating Actual } \\
\text { Performance }\end{array}$ & 0.735671 & 0.694431 & 0.695487 & 0.675911 & 0.726829 & $\mathbf{0 . 8 0 3 0 0 7}$ \\
\hline
\end{tabular}

Source: Data Results of SmartPLS 2.0 M3 (2016)

Table 2 above shows that all variables have a higher correlation value to their own variables than to other variables (see numbers in bold). This shows that the research model has met the discriminant validity test, so the reliability test is then carried out.

Test Reliability is done to determine the extent to which the measurement tool has accuracy and accuracy of measurements that are consistent over time. According to Chin in Ghozali (2008), an indicator is said to have good reliability if the value composite reliability is greater than 0.70 . Table 4 below shows values composite reliability to test the reliability of research instruments.

Table 3

Composite Reliability

\begin{tabular}{ll}
\hline & $\begin{array}{l}\text { Composite } \\
\text { Reliability }\end{array}$ \\
\hline Trust & 0.914232 \\
\hline Job Satisfaction & 0.896079 \\
\hline Knowledgeable Psychology Contract & 0.877384 \\
\hline Intrinsic Motivation & 0.89657 \\
\hline Award Mechanism & 0.879762 \\
\hline Assessment of Actual Performance & 0.915738 \\
\hline Source: Results of Data Exercise SmartPLS 2.0 M3 (2016)
\end{tabular}

Table 3 above shows that all the variables tested in this study have met the rule of thumb value composite reliability required, which is greater than 0.60 . This shows that all indicators in this study have met the validity and reliability test of measurement as the basis for testing instruments for testing structural models at a later stage.

Structural models were evaluated using $R$-Square $\left(\mathrm{R}^{2}\right)$ to construct the dependent and the significant value that is determined based on the value of the $t$ statistic of the $p$-value. The magnitude of the coefficient value of each path can be seen from the value original sample 
between constructs. The description of the research structural model along with the coefficient values of each path and the value of $\mathrm{R}^{2}$ of the dependent construct are shown in table 4 and table 5 below. The value $\mathrm{R}^{2}$ shows the magnitude of the variance that can be explained by the independent variable.

Table 4

R-Square

\begin{tabular}{|l|l|}
\hline & $\begin{array}{l}\text { Composite } \\
\text { Reliability }\end{array}$ \\
\hline Trust & \\
\hline Job Satisfaction & 0.513864 \\
\hline $\begin{array}{l}\text { Knowledgeable Contract } \\
\text { Psychology }\end{array}$ & 0.613183 \\
\hline Intrinsic Motivation & \\
\hline Award Mechanism & \\
\hline Actual Performance Assessment & \multicolumn{2}{|c|}{ Source: Results of Data Observer SmartPLS 2.0 M3 (2016) } \\
\hline
\end{tabular}

Table 4 above shows that the value of 0.513864 for variable contract psychology knowledgeable which means that knowledgeable psychology contract variances are able to explain the variance of job satisfaction by $51.38 \%$.

The value of the coefficient path or inner model shows the level of significance in testing the hypothesis. The score for the coefficient path or inner model shown by the T-value statistic, must be above 1.96 for the hypothesis two-tailed with $a=0.05$ and above 1.64 for the hypothesis two-tailed with $a=0.10$ (Hair et al., 2014). Table 5 shows the significance values of all hypotheses tested in this study.

\section{RESULTS AND DISCUSSION}

Data collected as much as 205 as many as 330 respondents means the return of questionnaires is $62.12 \%$. 
Table 5.

Total Effects (Mean, STDEV, T-Values)

\begin{tabular}{|l|l|l|l|l|l|}
\hline & $\begin{array}{l}\text { Original } \\
\text { Sample (O) }\end{array}$ & Mean (M) & $\begin{array}{l}\text { StandardSt } \\
\text { andard } \\
\text { Deviation } \\
\text { (STDEV) }\end{array}$ & $\begin{array}{l}\text { Standard } \\
\text { Error } \\
\text { (STERR) }\end{array}$ & $\begin{array}{l}\text { T Statistics } \\
\text { (I O / } \\
\text { STERR I) }\end{array}$ \\
\hline K -> KPP & $\mathbf{0 . 3 3 6 0 6 9}$ & 0.332718 & 0.144073 & 0.144073 & $\mathbf{2 . 3 3 2 6 3}$ \\
\hline MP -> KPP & $\mathbf{0 . 2 2 2 2 9 1}$ & 0.249824 & 0.121648 & 0.121648 & $\mathbf{1 , 8 2 7 3 3 5}$ \\
\hline PKA -> KPP & $\mathbf{0 . 1 7 2 0 1 2}$ & 0.167895 & 0.128264 & 0.128264 & $\mathbf{1 , 3 4 1 0 7 5}$ \\
\hline MI -> KPP & $\mathbf{0 . 1 6 9 6 5 4}$ & 0.15043 & 0.111232 & 0.111232 & $\mathbf{1 , 5 2 5 2 3 2}$ \\
\hline KPP -> KK & $\mathbf{0 . 4 4 0 0 8 2}$ & 0.4408 & 0.114424 & 0.114424 & $\mathbf{3 . 8 4 6 0 6 2}$ \\
\hline MI -> KK & $\mathbf{0 . 4 3 3 0 7 5}$ & 0.438268 & 0,091347 & 0.091347 & $\mathbf{4 , 7 4 0 9 8 6}$ \\
\hline
\end{tabular}

Source: Results of Data from the SmartPLS 2.0 M3 (2016)

*) Significant at $\mathrm{p}<0.05$ (two-tailed)

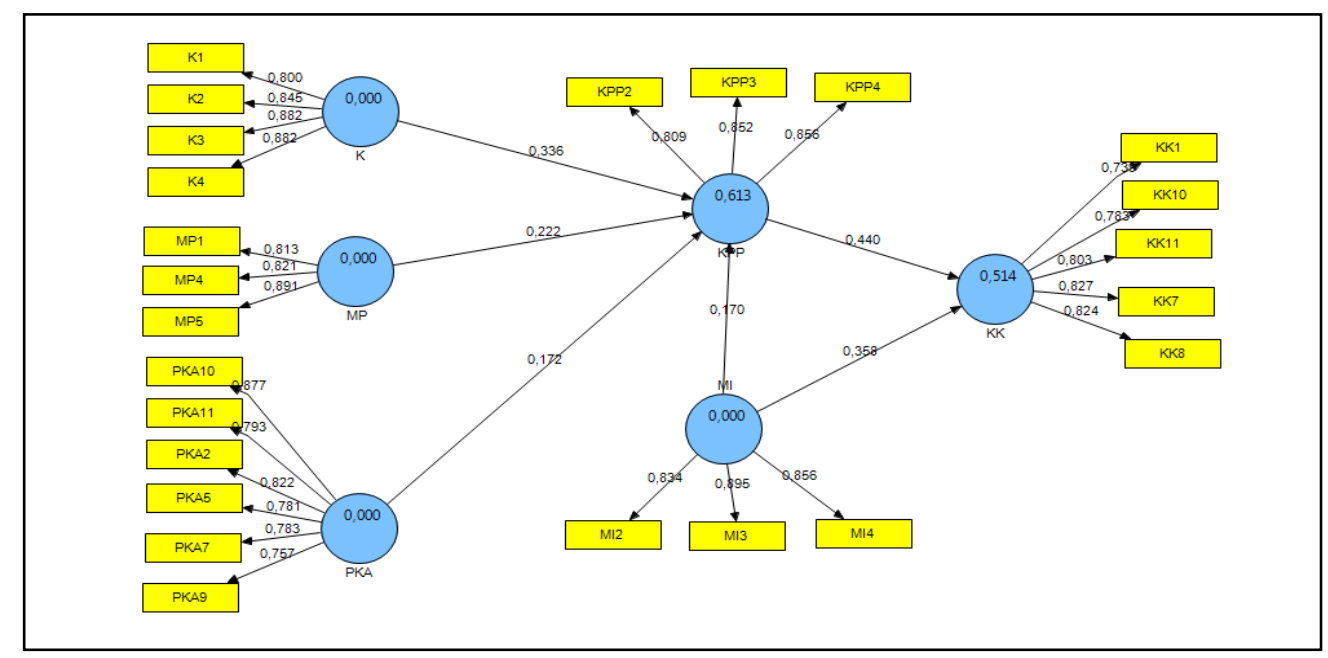

Figure 1. The Results of PLS Algorithm 


\section{CONCLUSION AND IMPLICATIONS}

Table 6

Conclusion of HypothesisTesting

\begin{tabular}{lll}
\hline Hypothesis & \multicolumn{1}{c}{ Statement of Hypothesis } & \multicolumn{1}{c}{ Results } \\
\hline H1 & $\begin{array}{l}\text { Degree of reciprocal trust has a positive effect on } \\
\text { the contract of psychological justice }\end{array}$ & Supported * \\
\hline H2 & $\begin{array}{l}\text { Progressive reward mechanism has a positive effect } \\
\text { on the contract of justice psychology }\end{array}$ & Not supported \\
\hline H3 & $\begin{array}{l}\text { Assessment of actual performance has a positive } \\
\text { effect on fair psychology contracts }\end{array}$ & Not supported \\
\hline H4 & $\begin{array}{l}\text { Intrinsic motivation positive effect on fairness } \\
\text { psychology contracts }\end{array}$ & Not supported \\
\hline H5 & $\begin{array}{l}\text { Equitable psychological contracts have a positive } \\
\text { effect on job satisfaction }\end{array}$ & Supported * \\
\hline H6 & $\begin{array}{l}\text { Intrinsic motivation has a positive effect on job } \\
\text { satisfaction }\end{array}$ & Supported * \\
\hline
\end{tabular}

Data Results SmartPLS 2.0 M3 (2016)

Note: testing is carried out attesting significance levels two-tailed

*) significant at $\mathrm{p}<0.05$

Tests of relationships between variables indicate that the influence of the variable trust in psychology contracts is positively knowledgeable (0.336069) and significant at $\alpha=0.05$ with a statistical value of 2.33263> 1.96. This finding answers the first research objective that examines the effect of trust in knowledgeable psychological contracts. The first hypothesis is supported, because statistically confidence has a significant effect on knowledgeable psychology contracts at the level of $\mathrm{p}<0.05$. This is in line with the research of Deery, Iverson, \& Walsh, 2006 where stating that contractual psychology violations can result in reduced elements of trust in relationships between organizations and employees, and often results in anger and low trust. In addition Coyle-Syapiro, 2002 also states that when both parties, namely organizations and employees maximize their relationships, then trust must be the main thing that provides a mechanism where both can work together effectively because the central role of trust in relationships has a direct influence on how the two work together.

The test of the relationship between variables showed that the effect of the mechanism of reward variable on psychology contracts was positively knowledgeable (0.222291) and significant at $a=0.05$ with a statistical value of $1.827335<1.96$. This finding answers the purpose of the second study that examined the mechanism of appreciation of knowledgeable psychological contracts. The second hypothesis is not supported, because of the mechanism of reward no significant effect on knowledgeable psychology contracts at $p<0.05$. 
The test of the relationship between variables shows that the effect of the actual performance assessment variable on the psychological contract is positively knowledgeable

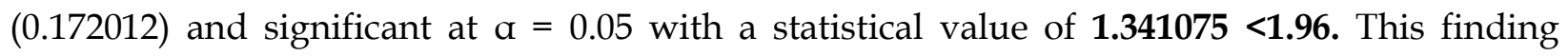
answers the third research objective that tests actual performance assessments of knowledgeable psychological contracts. The third hypothesis is not supported, because the assessment of actual performance does not have a significant effect on knowledgeable psychology contracts at the level of confidence $\mathrm{p}<0.05$.

Test relationships between variables indicate that the influence of intrinsic motivation variables on psychology contracts is positively knowledgeable (0.169654) and significant at $\alpha=$ 0.05 with values statistic $1.525232<1.96$. This finding answers the purpose of the fourth research that examines intrinsic motivation towards knowledgeable psychology contracts. The fourth hypothesis is not supported, because the assessment of intrinsic motivation has no significant effect on knowledgeable psychology contracts at the level of $p<0.05$.

The relationship of the influence of contract psychology variables knowledgeable to job satisfaction was also positive (0.440082) and significant at $a=0.05$ with a statistical value of 3.846062> 1.96. This finding answers the fifth research objective that examines the effect of knowledgeable psychology contracts on job satisfaction. The fifth hypothesis is supported, because statistically knowledgeable psychology contracts have a significant effect on job satisfaction at a level of $\mathrm{p}<0.05$. This is in line with the Brief \& Weis study, 2002 where job satisfaction is an internal statement expressed by cognitive and affective evaluations in the work environment with levels of likes or dislikes. Individuals who believe will get what they expect seems more satisfied with their work (Guest \& Conway, 1999). In line with Tekleab and Taylor (2003) research states that states that there is a correlation of -0.34 between psychological contracts and job satisfaction. When job satisfaction increases, contract psychology also increases (Lamberts, Edwards, and Cable (2003).

Test relationships between variables indicate the effect of the relationship of variables intrinsic motivation to job satisfaction is also positive (0.433075) and significant at $\alpha=0.05$ with statistical value $4,740986>1.96$. This finding answers the sixth research objective that examines intrinsic motivation to job satisfaction. The sixth hypothesis is supported, because statistically intrinsic motivation has a significant effect on job satisfaction at a $\mathrm{p}<0.05$ level. This is in line with Maurer \& Tarulli's research 1994 where in the context of training motivation can affect the 
Andalas Management Review, Vol. 3 No. 1, 2019

desire of employees to attend training programs. Some researchers show that there is a relationship between training motivation and training effectiveness (Facteau et., Al. 1995) Quinones (1995) Tabassi et., Al (2011) found that there was a relationship between the practice of training motivation on improving work teams and efficiency assignment. Among the types of motivation, intrinsic motivation has a large impact on employee attitudes (Deci \& Ryan, 2004). $\mathrm{Lu}(1999)$ reported that intrinsic motivation had a significant positive effect on job satisfaction.

\section{REFERENCES}

Agarwal, P., (2011). "Relationship between psychological contract \& organizational commitment in Indian IT industry.", Indian Journal of Industrial Relations, Vol 47, No. 2, pp. 290-305.

Alniacik, E., Alniacik, U., Erat, S. and Akcin, K., (2013), Does Person Organization Fit Moderate the Effects of Affective Commitment and Job Satisfaction on Turnover Intentions? Procedia-Social and Behavioral Sciences, Vol. 99, pp. 274-281.

Arasli, Huseyin., Daskin, Mustafa., \& Saydam, Serdar, (2014), Polychronocity and Intrinsic Motivation as Dispositional Determinants on Frontline Hotels Employees Job Satisfaction: Do Control Variables Make a Difference ?. Procedia - Social and Behavioral Sciences. Vol. 109, pp. 1395-1405

Ayeni, CO., \& Popoola, S., (2007), Work motivation, job satisfaction, and organizational commitment of the personal library in In Oyo State's academic and research libraries. Library Philosophy and Practice. pp.1-16.

Bowen, DE, \& Ostroff, C., (2004), Understanding HRM - Firm Performance Linkages: The Role of the Strength of the HRM System. Academy of Management Review, Vol. 29 No. 20, pp. 203-221.

Cappelli, P., \& Neumark, D., (1999), Do High Performance Work Practices Improve Establishment Work Outcomes? Industrial and Labor Relations Review, Vol. 54, No. 4, pp. 737- 775.

Chang, LC, Shih, CH \& Lin. SM., (2010), “The mediating role of psychological empowerment on job satisfaction and organizational commitment for school health nurses: A crosssectional quetionaire survey.", International of Journal Nursing Studies. Vol. 47. pp. 427433.

Chen, G., Kirkman, BL, kanfer, R., Allen, D., \& Rosen, B., (2007), “A multilevel study of leadership, empowerment and performance in teams", Journal Applied Psychology, Vol 92, No. 2, pp. 331-346.

Chen G \& Klimoski RJ, (2007), Training and development human resources work Is the state of our science strong? Human Resource Management Review, Vol. 17, pp. 180-190.

Clinton, M. \& Guest, DE., (2004), "Fulfillment of the Psychological Contract and Associated Work Attitudes: The Role of Fairness and Trust", Paper presented at the BPS division of Occu pational Conference, Stratford, UK.

Cooper, DR, \& Schindler, PS., (2008), Business Research Methods. Issue 10. Inc. New York: The McGraw-Hill Companies.

Coyle-Shapiro, JAM., (2002), “A psychological contract perspective on organizational citizenship behaviors", Journal of Organizational Behavoir, Vol. 23, pp. 927-46. 
Coyle-Shapiro J. and Kessler I., (2002), “Exploring Reciprocity through the Lens of the Psychological Contract: Employee and Enployeer Perspective.", Euroepe Journal of Work Organizational Psychology, Vol. 11, No. 1, pp. 69-86.

Darolia, CR, Kumari, P., \& Darolia, S., (2010), "Perceived organizational support, work motivation and organizational commitment as determinants of job performance.", Journal of the Indian Academy of Applied Psychology, Vol. 36, No. 1, pp. 68-78.

Davies, R., (2001), How to Boost Staff Retention. People Management, Vol. 7, No. 8, pp. 54-56.

Deci. EL, \& Ryan, RM., (2004), Handbook of Self-Determinatio Reserach. Rochester, NY: University of Rochester Press.

Deci.EL \& Moller, AC., (2005), The concept of competence - A starting place for understanding intrinsic motivation and self-determined extrinsic motivation. In A. J Elliot \& CS Dweck (eds). Handbook of Competence and Motivation (New York: The Guilford Press). pp. 579597.

DeCicco.J., Laschinger.H. Kerr. M., (2006), "Perceptions of empowerment and respect; effect on access to organizational commitment in nursing home." , Journal of Gerontological Nursing, Vol. 32, No. 5, pp. 49-56.

Deery, SJ, Iverson, RD, \& Walsh, JT (2006), “Towards a Better Understanding of Psychological Contract Breach; A Study of Customer Service Employees", Journal of Applied Psychology, Vol. 91, No. 1, pp. 166-175.

Dewettink, K., Singh, J. \& Buyens, D., (2003), "Psychological Empowerment in the Workplace; Review the Empowerment Effects on Critical Work Outcomes, Vlerick Leuven Gent Working Paper Series, Ghent University, pp. 2-26.

Ghozali, Imam. (2008). Structural Equation Modeling Alternative Methods with Partial Least Square (PLS). Semarang: University Publishing AgencyDiponegoro.

Guest, DE, \& Conway, N. (2002). "Communicating psychological contracts between employer perspectives.", Human Resource Management Journal, Vol. 12, pp. 22-38.

Guthrie. JP (2001). “High Involment Work Practices, Turnover and Productivity: Evidence from New Zealand", Academy of Management Journal, Vol. 44, No. 1, pp. 180-90.

Hair, Joseph. F.Jr., William C. Black., Barry J. Babin., And Rudolp E. Anderson, (2010), Multivariate Data Analysis, 7th ed. Upper Saddle River, New Jersey, Printice Hall International, Inc.

Huczynski, AA, \& Buchanan, DA (2007). Organizational Behavior, FT Prentice Hall.

Jonhson, JL, \& OLeary-Kelly, AM (2003). “Contractual Breach and Organizational Cynicism; Not All Social Exchange Violations are Created Equal.", Journal of Organizational Behavior, Vol. 24, pp. 627-647.

Johnson, RE, Chang.CH, \& Yang, LQ (2010). Commitment and Motivation at Work, The Relevance of Employee Identity and Regulatory Focus. Academy Management Review, Vol. 35, pp. 226-245.

Kim, WC, \& Mauborgne, R. (2003). Fair Process: Managing in Knowledge Economy, Harvard Business Review, pp. 127-136.

Lambert, SJ, Edwards, JR, \& Cable, DM. (2003). Breach and Fulfillment of the Psychological Contract; A Comparison of Traditional and Expanded Views. Personnel Psychology, Vol. 56, No. 4, pp. 895-933.

Lange, HA, dkk. (2011). When I'm 64: Psychological contract breach, work motivation and moderating regulatory focus, Work $\mathcal{E}$ Stressfuture time perspective and regulatory roles, Vol. 25, No. 4, pp. 338-354. 
Leat.M. \& El-Kot. G. (2009). "Interpersonal Trust at Work, Intrinsic Motivation, Work Related Tension and Satisfaction in Egypt.", International Journal of Workplace Health Management, Vol. 2, No. 2, pp. 180-194.

Lee.AN \& Nie.Y. (2014). Understanding Teacher Empowerment; Teachers Perceptions of Primer's and Immediate Supervisor's Empowering Behavior, Psychological Empowerment and Work Related Outcomes. Teaching and Teacher Education. Vol. 41. pp. 67-79.

Lester, SW, Claire, F., \& Kickul, J. (2001). Psychological Contract in the 21 $1^{\text {st }}$ Century; What Employee Value Most and How Well Organizations are Resonding to the Expectations. Human Resource Planning, Vol. 24, NO. 1, pp. 10-21.

Lester, SW, dkk. (2002). "Not Seeing Eye to Eye; Difference in Supervisors and Subordinate Perceptions of Attributes for Psychological Contract Breach." Journal of Organizational Behavior, Vol. 23, No. 1, pp. 39-56.

Liden. RC, Wayne.SJ, \& Sparrowe.RT (2000). "An Examination of the Mediating Role of Psychological Empowerment on Relations between the Job, Interpersonal Relationship, and Work Outcomes." Journal of Applied Psychology. Vol. 85. pp. 407-416.

Lijo. KJ, \& Amrutha, P. (2013). “Job involvement of Textile employees with regards to quality of life. International." Journal for Research and Development, Vol. 1, No. 4, pp. 27-30.

Lilo, KJ \& Lyngdoh. WS, (2016). "Psychological Contract and Job Satisfaction among HR Professionals in Start-up Service Sector." The International Journal of Indian Psychology. Vol 3, No.2, pp. 2439-3429.

Liu, AMM, \& Fang, Z. (2006). A Power Based Approach to Project Management leadership, Construction Management Economic, Vol. 24, No. 5, pp. 497-507

Low, CCP, \& Robertson, RW (2006). Not for bread alone; motivatioan among Hospital employee in Singapore, Public Organization Review. pp. 155-166.

Meyer. JP, \& Smith. CA (2000). "HRM practices and organizational commitment: Test of a mediation model." Canadian Journal of Administrative Sciences, Vol. 17, No. 4, pp. 319-331.

Parker, SK, \& Turner, N. (2002). Work design and individual work performance: Research finding and an agenda for future inquiry. In. Psychological management of individual performance, S. Sonnentag, John Wiley, Chichester, pp. 69-93

Parker, O., \& Wright, L. (2001). "Pay and Employee Commitment." The Missing Link, Ivey Bussiness Journal, Vol. 65, No. 3, pp. 70-79.

Paul, RJ, Niehoff, BP, \& Turnley, WH (2000). "Empowerment, Expectations, and the Psychological Contract - Managing the Dillemas and gaining the Advantages." Journal of Socio-Economics, Vol. 29, pp. 471-485.

Quinones, MA (1995). "Pretraining Context Effect: Training Assignment as Feedback." Journal of Applied Psychology. Vol. 80. pp. 226-238.

Rousseau, DM (1990). "New Hire Perceptions of Their Own and Theirs Employees Obligations; A Study of Psychological Contract." Journal of Organizational Behavior, Vol. 11, pp. 389400.

Rousseau, DM (2001). "Schema, promise, mutuality; the building blocks of the psychological contract", Journal of Occupational and Organizational Psychology, Vol. 74, pp. 511-41.

Rowden, RW, \& Conine, CT (2005). "The impact of workplace learning and job satisfaction in small US commercial banks", Journal of Workplace Learning, Vol. 17, No. 4, pp. 215-230

Schuler, RS (1987). Human Resource Management Practice Choices. Human Resource Planning, Vol. 10, pp. 1-19. 
Sebastian, MS, \& AP, DG (2015). "Psychological Contract in the Indian Aviation." Indian Journal Of Research. Vol 8, pp. 78-94.

Seibert.SE, Wang. G., \& Courtright. SH (2011). "Antecedents and Consequences of psychological and team empowerment in organizations: A meta-analytic review." Journal of Applied Psychology. Vol. 96. No. 5. pp.981-1003.

Sonnenberg.M, Co. B, \& Paauwe. J. (2011). HRM Balancing; The psychological contract of employees; A Multi Level Study. Personal Review, Vol. 40, No.6, 2011, pp. 664-683.

Spreitzer.GM (2008). Taking Stock: A review of more than twenty years of research on empowerment work. In J. Barling \& CL Cooper (eds). Handbook of Organizational Behavior. Thousand Qaks, CA: Sage. pp. 54-72.

Tabassi. AA, Ramli. M., \& Burn. AHA (2012). "Effects of training and motivation on teamwork improvement and task efficiency: The case of construction firms." International Journal of Project Management, Vol. 30, pp. 213-224.

Tekleab, AG, \& Taylor, MS (2003). "Arent There are Two Parties in an Employment Relationship? Antecedent and Consequences of Organization Employee Agreement and Contract Obligations and Violations." Journal of Organizational Behavior, Vol. 24, pp. 585608.

Tracey. JB, Timothy. R., Mathieu .JW, (2001). The individual influences of characteristics and work environment on varying level of training outcomes. Human Resource Development International, Vol. 12, pp. 5-23.

Tsai. P. Yen, CY, Huang. L. \& Huang. I. (2007). “A study on motivating employee's learning commitment in the post-downsizing era: job satisfaction perspective." Journal of World Business, Vol. 4, No. 2, pp. 157-169.

Ulrich.D. (1997). Human Resource Champions, Boston, MA: Harvard University Press.

Wang. H. (2010). Analysis of the influence of psychological empowerment to intrinsic motivation for first line employees in service business; An empirical analysis of banking line. Psychology Research. Vol. 01. pp. 1838-658x

Zhang, X., \& Bartol, KM (2010). "Linking empowerment leadership and employee creativity: The influence of psychological empowerment, intrinsic motivation, and creative process engagement", Academy of Management Journal, Vol. 53, No. 1, pp. 107-128.

Zhou, J., Plaisent, M., Zheng, L \& Bernard, P. (2014). "Psychological Contract, Organizational Commitment and Work Satisfaction: Survey of Researchers in Chinese State-Owned Engineering Research Institutions", Open Journal of Social Sciences, Vol. 2, pp. 217-225. 